\title{
STUDY ON HYDROGEN PRODUCTION OYF BIO-OIL CATALYTIC REFORMING BY CHARCOAL CATALYST
}

\author{
ZHANG, Y. \\ College of Chemical Engineering, Guangdong University of Petrochemical Technology, \\ Maoming 525000, China \\ (e-mail: 280512356@qq.com; fax: +86-066-8298-1080)
}

(Received $8^{\text {th }}$ Mar 2019; accepted $21^{\text {st }}$ May 2019)

\begin{abstract}
In this study Charcoal was used as a primary bio-oil steam reforming catalyst. The performance of the catalyst was investigated. The dynamic parameters of the first order dynamic equation were calculated. The stability of charcoal was also examined. The results indicated that first, when reforming temperatures were lower than $700{ }^{\circ} \mathrm{C}$, the bio-oil contents in the outlet dry gas were very high. This indicated unsuitability for further catalytic reforming over a metal catalyst. Second, the catalytic activity of charcoal became very significant under high temperature conditions $\left(\geq 800^{\circ} \mathrm{C}\right)$; thus, the apparent activation energy of the first order kinetic rate constant is $56.98 \mathrm{~kJ} / \mathrm{mol}$, and the pre-exponential factor is $1.58 \times 10^{4} \mathrm{~s}^{-1}$. Third, the bio-oil contents in the outlet dry gas varied from a decrease to a slight increase in the first $2 \mathrm{~h}$ under a catalytic reforming temperature of $900{ }^{\circ} \mathrm{C}$, a WHSV (weight hourly space velocity) of $2.6 \mathrm{~h}^{-1}$, a bio-oil feeding rate of $47.02 \mathrm{~g} / \mathrm{h}$, and a S/B (mass steam-to-bio-oil) ratio of 2. Overall, the charcoal exhibited an excellent bio-oil removal rate (conversion > 99.6\%) and the bio-oil contents in the outlet dry gas were lower than $1.89 \mathrm{~g} / \mathrm{Nm}^{3}$, hence signifying suitability for further reforming over metal catalysts.
\end{abstract}

Keywords: catalyzer, stability, char, gas cleaning, steam reforming process

\section{Introduction}

Interest in the hydrogen economy is increasing due to its potential applications in hydrogen fuel cell vehicles and fuel cell power generation ( $\mathrm{Li}$ et al., 2018). Currently, the main hydrogen production processes are catalytic reforming of naphtha, light hydrocarbons and methane (Zhou et al., 2017a), while coal gasification is also widely used (Zhang, 2018; Daniel et al., 2018). However, the sustainable energy development can be realized only by using renewable energy as raw material to produce hydrogen (Bizkarra et al., 2018; Hossain et al., 2019). In this regard, steam reforming of bio-oil has been reported in many journals (Beatriz et al., 2018; Asghar et al., 2018). Bio-oil is produced by rapid pyrolysis of biomass. And its main components include alcohol, furan, acid, sugar, phenol, ketone and aldehyde (Arandia et al., 2018; Ilyas et al., 2018). The catalytic reforming of bio-oil mainly depends on the catalytic capacity of the catalyst for steam reforming reaction $\left(\mathrm{C}_{n} \mathrm{H}_{m} \mathrm{O}_{\mathrm{k}}+(\mathrm{n}-\mathrm{k}) \mathrm{H}_{2} \mathrm{O}=(\mathrm{n}+\mathrm{m} / 2-\mathrm{k}) \mathrm{H}_{2}+\mathrm{nCO}\right)$ and water gas shift reaction $\left(\mathrm{CO}+\mathrm{H}_{2} \mathrm{O}=\mathrm{H}_{2}+\mathrm{CO}_{2}\right)$. When bio-oil is reformed at high temperature, the Boudoard reaction $\left(2 \mathrm{CO}=\mathrm{C}+\mathrm{CO}_{2}\right)$ and partial thermal decomposition of bio-oil may occur simultaneously (Zhou et al., 2017b).

Preliminary economic analysis shows that bio-oil steam reforming for hydrogen production is profitable in the current market (Czernik and French, 2014; Omini and Akpang, 2018). However, bio-oil catalytic reforming for hydrogen production is still facing many technical difficulties in order to become a commercially mature technology. Zeng et al. (2015) and Rajput et al. (2019) reported that carbon deposition on catalyst supports leads to low purity hydrogen in gas products. Li et al. (2017) proposed that a significant challenge in bio-oil hydrodeoxygenation was the 
deactivation of coke deposits on zeolite catalysts. Wu et al. (2008) proposed dolomite catalyst with low cost to be chosen as the first-order catalyst for tar steam reforming, and then methane and tar are further reformed on nickel metal catalyst (Zhang et al., 2017). This technological process can protect the metal catalyst from quick deactivation and the economic loss could be reduced efficiently (Li et al., 2008). This technological process can effectively prevent the rapid deactivation of nickel metal catalysts and reduce economic losses (Cho et al., 2014; Yahya et al., 2018). However, since the calcined dolomite is easy to break up under the impact of air flow, powder dolomite may cause the resistance of the catalyst bed to rise sharply (Thakkar et al., 2016).

The research on catalytic reforming of tar over charcoal during biomass gasification can be used as a reference for steam reforming of bio-oil (El-Rub et al., 2008; Masri and Samsudin, 2018). Char itself has some activity for biomass tar conversion (Nestler et al., 2016), and its conversion activity is affected by surface area (Mun et al., 2010), pore size and ash composition (Zanzi et al., 1996). The coke deposited on the charcoal will block the pore and reduce the surface area, thus reducing the activity of the charcoal. However (Morishita et al., 2002), coke can also be consumed by gaseous products such as steam and carbon dioxide, and its deactivation can be suppressed by generating new pores (Hosokai et al., 2005; Sharma and Yadav, 2018). Furthermore, char catalysts would have low costs and be simply burned/gasified to recover the energy of the char without the need of often expensive regeneration after deactivation (Li, 2007). Hence, choosing a char catalyst as the primary steam reforming catalyst is more promising (Kai et al., 2018). It is important to study the catalytic activity and stability of the char catalysts for bio-oil conversion.

In this study, char is used as a primary steam reforming catalyst (Min et al., 2011; Naidu et al., 2018). The catalytic performance of the catalyst for bio-oil catalytic steam reforming under different operating conditions was studied. The stability of the charcoal catalyst was also investigated. The kinetic parameters were calculated by using the firstorder kinetic equation (Qian and Kumar, 2015).

\section{Materials and Methods}

\section{Test material}

Bio-oil was produced by rapid pyrolysis of sawdust with fluidizer $\mathrm{N}_{2}$ in the temperature range of 450 to $500{ }^{\circ} \mathrm{C}$. The reactor used was a fluidized bed designed by East China University of Technology (Shanghai, China). Bio-oil components were determined by a gas chromatography-mass spectrometry. The results are shown in Table 1 .

\section{Properties of char}

The commercial charcoal was supplied by Shanghai Canature Environmental Products Co., Ltd. (Shanghai, China). Elemental analysis of dried samples showed that it contained $\mathrm{C} 74.09 \%, \mathrm{O} 17.51 \%, \mathrm{H} 4.80 \%, \mathrm{~S} 0.018 \%$ and $\mathrm{N} 0.1 \%$. Industrial analysis showed that ash content was $3.48 \%$.

Before the catalytic test, the commercial biomass charcoal was heated to $900{ }^{\circ} \mathrm{C}$ at a heating rate of $27 \mathrm{~K} / \mathrm{min}$ under the condition of air isolation, and the temperature was maintained for $30 \mathrm{~min}$. Table 2 shows the elemental analysis and ash content of the treated charcoal samples. Elemental $\mathrm{C}, \mathrm{N}$, and $\mathrm{H}$ analyses were performed using an 
elemental analyzer, Elementar Vario EL III (Langenselbold, Germany). A sulfur analysis was accomplished on a Coulomb sulfur analyzer, CLS-2 (Jiangsu Jiangfen Electric Instrument Co. Ltd., Jiangyan, China). The composition of ash was determined via Sequential X-ray fluorescence spectrometry, (XRF-1800, Thermofisher, Beijing, China). The char samples were screened to the particle sizes of $1 \mathrm{~mm}$ to $2 \mathrm{~mm}$.

\section{Installation and procedure for experiment}

As shown (Fig. 1), the catalytic reforming was performed in a fixed-bed reactor made of stainless steel. The height and diameter of the reactor are $800 \mathrm{~mm}$ and $20 \mathrm{~mm}$ respectively. The reaction pressure is atmospheric. The char catalysts were placed in the middle of the fixed-bed tube and the fixed bed was heated by an electric heating furnace equipped with a temperature control device. The nitrogen purged the system prior to the reactor heating. Bio-oil and water were fed into the reactor at a constant rate by two separate metering pumps. The reaction products were first condensed by tap water, then by ice-water mixtures, and the condensate was collected in liquid containers. The noncondensed components of the product gases were determined using an online gas analyzer (Gasboard-3100, Cubic Optoelectronics Co., Ltd., Wuhan, China) and the gas flow rate was measured using a soap membrane flow-meter (Agilent technologies Co., Ltd., Santa Clara, USA). When the feed is finished, the reactor is cooled to room temperature by nitrogen flow with a flow rate of $0.6 \mathrm{~L} / \mathrm{min}$, then the char catalysts are collected and weighed.

Table 1. Components of bio-oil

\begin{tabular}{|c|c|c|c|}
\hline Name & Area (\%) & Name & Area $(\%)$ \\
\hline Acetaldehyde & 2.81 & 2-methyl-2-Pentenal & 0.28 \\
\hline Methanol & 5.83 & Phenol & 1.23 \\
\hline Acetone & 1.27 & Unknown & 0.48 \\
\hline Unknown & 0.49 & 2-Hydroxy-3-methyl-2-Cyclopenten-1-one & 1.22 \\
\hline 2-Pentanone & 0.33 & 2-methyl-Phenol & 0.78 \\
\hline Pentane & 0.16 & 2-methoxy-Phenol & 0.85 \\
\hline Formic acid & 0.86 & 4-methyl-Phenol & 1.48 \\
\hline Unknown & 2.18 & 3,4-dimethyl-Phenol & 0.45 \\
\hline Acetic acid & 20.34 & 2-methoxy-4-methyl-Phenol & 0.98 \\
\hline 1-hydroxy-2-Propanone & 11.49 & 1,2-Benzenediol & 3.44 \\
\hline Propanoic acid & 0.81 & 4-ethyl-2-methoxy-Phenol & 0.36 \\
\hline 3-hydroxy-2-Butanone & 1.25 & 3-methoxy-1,2-Benzenediol & 0.21 \\
\hline 1-(acetyloxy)-2-Butanone & 1.83 & 4-hydroxy-Benzenemethanol & 0.76 \\
\hline 2-methyl-Pentanal & 0.83 & 2,6-dimethoxy-Phenol & 1.21 \\
\hline Propanoic acid,2-oxo-, methyl ester & 0.52 & 2-methoxy-4-(1-propenyl)-Phenol & 0.10 \\
\hline Unknown & 0.78 & Vanillin & 0.16 \\
\hline Furfural & 2.15 & 1,2,4-Trimethoxybenzene & 0.52 \\
\hline 2-Cyclopenten-1-one & 0.36 & Unknown & 0.20 \\
\hline 2-Butanone & 0.77 & 1-(4-hydroxy-3-methoxy phenyl)-Ethanone & 0.18 \\
\hline 1-(acetyloxy)-2-Propanone & 0.46 & 1,2,3-trimethoxy-5-methyl-Benzene & 0.19 \\
\hline 2-methyl-2-Cyclopenten-1-one & 0.27 & 1-(4-hydroxy-3-methoxy phenyl)-2-Propanone & 0.22 \\
\hline Butyrolactone & 0.30 & D-Mannoheptulose & 0.91 \\
\hline 2(5H)-Furanone & 1.04 & 2,6-dimethoxy-4-(2-propenyl)-Phenol & 0.60 \\
\hline 2-hydroxy-2-Cyclopenten-1-one & 0.44 & D-Allose & 23.68 \\
\hline 5-methyl-2(5H)-Furanone & 0.21 & 1-(4-hydroxy-3,5-dimethoxyphenyl)-Ethanone & 0.45 \\
\hline 5-methyl-2-Furancarboxaldehydehyde & 0.42 & 1,1'-butylidenebis-Benzene & 0.49 \\
\hline 3-methyl-2-Cyclopenten-1-one & 0.38 & & \\
\hline
\end{tabular}


Table 2. Elemental analysis and ash composition of the ultimate charcoal samples

\begin{tabular}{|c|c|c|c|c|c|c|c|}
\hline \multicolumn{8}{|c|}{ Ultimate analysis (wt.\%, dry basis) } \\
\hline $\mathrm{C}$ & \multirow{2}{*}{\multicolumn{2}{|c|}{$\begin{array}{l}91.03 \\
0.024\end{array}$}} & $\mathrm{O}$ & 2.766 & \multirow{2}{*}{\multicolumn{2}{|c|}{$\begin{array}{c}\mathrm{H} \\
\text { Ash }\end{array}$}} & 1.05 \\
\hline $\mathrm{S}$ & & & $\mathrm{N}$ & 0.14 & & & 4.99 \\
\hline \multicolumn{8}{|c|}{ Ash composition (\%) } \\
\hline $\mathrm{K}_{2} \mathrm{O}$ & 8.3240 & $\mathrm{MgO}$ & 12.3426 & $\mathrm{CaO}$ & 57.2088 & $\mathrm{SiO}_{2}$ & 8.1264 \\
\hline $\mathrm{SO}_{3}$ & 2.0576 & $\mathrm{Fe}_{2} \mathrm{O}_{3}$ & 2.6929 & $\mathrm{P}_{2} \mathrm{O}_{5}$ & 4.6305 & $\mathrm{MnO}$ & 0.0736 \\
\hline $\mathrm{Al}_{2} \mathrm{O}_{3}$ & 1.4948 & $\mathrm{SrO}$ & 0.5573 & $\mathrm{TiO}_{2}$ & 0.1616 & $\mathrm{CuO}$ & 0.1614 \\
\hline $\mathrm{ZnO}$ & 0.0739 & $\mathrm{Cl}$ & 0.1273 & $\mathrm{ZrO}_{2}$ & 0.1286 & $\mathrm{Na}_{2} \mathrm{O}$ & 1.6748 \\
\hline $\mathrm{NiO}$ & 0.0717 & $\mathrm{BaO}$ & 0.0475 & $\mathrm{Cr}_{2} \mathrm{O}_{3}$ & 0.0269 & $\mathrm{Rb}_{2} \mathrm{O}$ & 0.0100 \\
\hline $\mathrm{Co}_{2} \mathrm{O}_{3}$ & 0.0062 & $\mathrm{Y}_{2} \mathrm{O}_{3}$ & 0.0017 & & & & \\
\hline
\end{tabular}

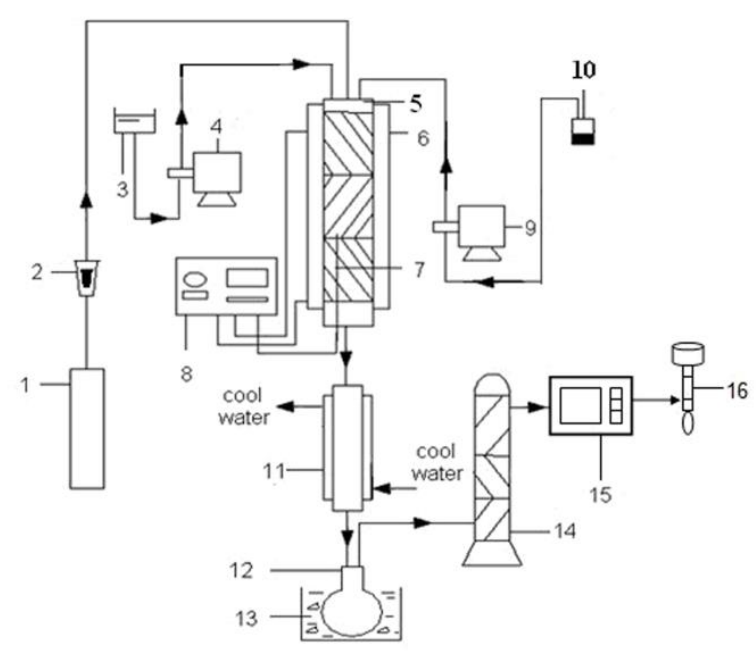

Figure 1. Schematic diagram of experimental device; 1) Nitrogen cylinder, 2) Gas flow indicator, 3) Water, 4) Meterflow pump I, 5) Fixed bed reactor, 6) Heating tube, 7)

Thermocouple, 8) Temperature controller, 9) Meterflow pump II, 10) bio-oil, 11) Condenser, 12) Liquid collector, 13) Ice-water bath, 14) Drying tower, 15) GC, and 16) soap membrane flow-meter

\section{Analysis of bio-oil in liquid condensate}

TOC (Total Organic Carbon) method was used to analyze liquid products. Liquid products can be divided into water-soluble and non-water-soluble substances, namely light hydrocarbons and heavy hydrocarbons, and oxygenates. Both fractions were called 'tars.' Although the water-soluble tar was a complex mixture of organic compounds, phenol represented the "average" tar compound. The tar yield determination was made in the same manner as previously indicated by Corella et al. (1991).

\section{Experimental data evaluation}

The conversion of bio-oil was calculated from their mass inlet and outlet as shown in Equation 1: 


$$
X=\frac{F_{\text {in }}-F_{\text {out }}}{F_{\text {in }}} \times 100
$$

where $X(\%)$ is the bio-oil conversion, $F_{\text {in }}(\mathrm{g})$ is the total mass of the inlet bio-oil, and $F_{\text {out }}(\mathrm{g})$ is the total mass of the outlet bio-oil.

The main property selected for determining the suitability of further catalytic steam reforming over a metal catalyst was the bio-oil contents in the outlet dry gas $(Y)$. It was defined as the ratio of the mass flow rate of bio-oil $(\mathrm{g} / \mathrm{min})$ over the flow rate of dry gas $\left(\mathrm{Nm}^{3} / \mathrm{min}\right)$ in an outlet as shown in Equation 2:

$$
Y=F_{\text {out }} /\left(\text { Total vol. of non-condensed gaseous products except for } \mathrm{Nm}^{3}\right. \text { ) }
$$

The residence time (s) in the catalyst bed were defined as Equation 3:

$$
t=\frac{\varepsilon \times V_{\text {char }}}{Q_{i n, T}}
$$

where $\varepsilon$ (dimensionless) was the bed porosity of the catalyst (with a value of $0.38 \mathrm{in}$ ), $V_{\text {char }}$ was the volume (L) of char in the bed, and $Q_{i n, T}$ was the total inlet flow rate (L/s) of $\mathrm{N}_{2}$, bio-oil, and water vapor under reactor temperature. The $Q_{i n, T}$ was calculated by the equation for the state of ideal gas, as shown in Equation 4:

$$
Q_{i n, T}=\frac{1000 \times F_{\text {inlet }, n} \times R \times T}{P}
$$

where $F_{\text {inlet,n }}(\mathrm{mol} / \mathrm{s})$ was the total inlet molar flow rate of $\mathrm{N}_{2}$, bio-oil, and water vapor, $\mathrm{R}=8.314(\mathrm{~J} / \mathrm{mol} / \mathrm{K}), T(\mathrm{~K})$ is the reactor temperature, and $P=101325(\mathrm{~Pa})$.

\section{Results and discussion}

\section{Effect of catalytic reforming temperature}

The effects of catalytic reforming temperatures in the range from 600 to $900{ }^{\circ} \mathrm{C}$ on the dry gas composition, bio-oil conversion, and bio-oil contents in the outlet dry gas were investigated while the $\mathrm{N}_{2}$ flow rate, WHSV (Weight hourly space velocity), feeding rate of bio-oil, and S/B (mass steam-to-bio-oil ratio) were fixed at $30 \mathrm{~mL} / \mathrm{min}$, $5.2 \mathrm{~h}^{-1}, 47.02 \mathrm{~g} / \mathrm{h}$, and 2, respectively. As can be seen from Table 3, as expected, the concentration of hydrogen in the gaseous product and the bio-oil conversion increased with the catalytic reforming temperature, while the concentration of carbon dioxide in the gaseous product and the bio-oil content in the outlet dry gas decreased. Comparing the results with that of Wang et al. (2007), it can be seen that the catalytic activity of the char catalyst is higher than the $\mathrm{C} 12 \mathrm{~A} 7-\mathrm{O}^{-} / 18 \% \mathrm{Mg}$ catalyst at 600 to $700{ }^{\circ} \mathrm{C}$. This indicated that the char catalyst had good catalytic performance for the bio-oil conversion. However, comparison with the results of Wang et al. (Wang et al., 1998) found that the total concentration of $\mathrm{H}_{2}$ and $\mathrm{CO}$ was about $80 \%$ over the commercial catalysts of the UCI G-90C and ICI 46-series. Nevertheless, the total composition of $\mathrm{H}_{2}$ and $\mathrm{CO}$ was lower than $64 \%$ over the char catalyst at 800 to $900{ }^{\circ} \mathrm{C}$. A reason for this was because the concentration of $\mathrm{CH}_{4}$ in the gaseous product was high. This indicated 
that the char catalyst had limited effects on the $\mathrm{CH}_{4}$ transformation (Yang et al., 2019). When the temperature was lower than $700{ }^{\circ} \mathrm{C}$, the bio-oil contents in the outlet dry gas was very high, and therefore is not suitable for further catalytic steam reforming over the metal catalyst. The catalytic activity of char became very prominent at high temperatures $\left(\geq 800{ }^{\circ} \mathrm{C}\right.$ ). The bio-oil conversion was higher than $80 \%$ and the bio-oil contents in the outlet dry gas became much lower, though the technological parameters should be further optimized to reduce the bio-oil contents in outlet dry gas.

Table 3. Effects of catalytic reforming temperatures on dry gas composition and bio-oil conversion as well as bio-oil contents in outlet dry gas

\begin{tabular}{c|c|c|c|c|c|c}
\hline \multirow{2}{*}{$\begin{array}{c}\text { Temperature } \\
\left({ }^{\circ} \mathbf{C}\right)\end{array}$} & \multicolumn{3}{|c|}{ Dry gas composition (vol.\%) } & \multicolumn{2}{c}{ Bio-oil } \\
\cline { 2 - 7 } & $\mathbf{H}_{\mathbf{2}}$ & $\mathbf{C O}$ & $\mathbf{C H}_{\mathbf{4}}$ & $\mathbf{C O}_{\mathbf{2}}$ & Conversion (wt.\%) & In outlet dry gas $\left(\mathbf{g} / \mathbf{N m}^{\mathbf{3}}\right)$ \\
\hline 600 & 0.33 & 6.14 & 17.45 & 76.09 & 49.00 & 2664.44 \\
700 & 12.24 & 10.84 & 21.79 & 55.13 & 62.65 & 1105.79 \\
800 & 18.62 & 19.50 & 27.93 & 33.95 & 82.22 & 237.50 \\
900 & 45.85 & 18.36 & 11.34 & 24.45 & 93.87 & 53.25 \\
\hline
\end{tabular}

\section{Kinetic aspects of catalytic reforming}

From the previous sections it was found that the catalytic activity of char became very significant at high temperatures above $800{ }^{\circ} \mathrm{C}$. The temperature and char dosage effects on the bio-oil conversion were studied in the temperature range of 800 to $900{ }^{\circ} \mathrm{C}$ and the char dosage range of 9 to $18 \mathrm{~g}$.

A first order kinetic equation is used to calculate the kinetic parameters (Eq. 5), for the overall bio-oil catalytic reforming reactions:

$$
\frac{d F}{d t}=-k F
$$

where $F(\mathrm{~mol} / \mathrm{s})$ is the molar flow rate of bio-oil at the reactor inlet and $k$ is the apparent kinetic constant.

To verify plug flow conditions in the fixed bed, the longitudinal or axial dispersion coefficient $(D)$, which characterizes the degree of back mixing during the flow, needed to be calculated. This coefficient is used in the dimensionless Peclet number $(\mathrm{Pe})$ to determine the type of flow, according to Equation 6:

$$
P e=\frac{v \times L}{D}
$$

$P e \rightarrow 0$ large dispersion, hence the use of a mixed flow; $P e \rightarrow \infty$ negligible dispersion, hence the use of a plug flow, where $L$ is the length of the bed (units) and $\mathrm{m}$ and $v$ are the average actual fluid velocity $(\mathrm{m} / \mathrm{s})$.

The Peclet number was very high (approximately $1.81 \times 10^{4}$ ), hence the plug flow conditions can be assumed. Under the plug flow conditions, the first-order kinetic equation can be integrated according to Equation 7: 


$$
\ln \left(\frac{F_{\text {in }}}{F_{\text {out }}}\right)=k t
$$

The slopes of those lines were calculated by a linear regression to give the apparent kinetic constant, $k$, under the catalytic gasification temperature of $800{ }^{\circ} \mathrm{C}, 850{ }^{\circ} \mathrm{C}$, and $900{ }^{\circ} \mathrm{C}$ as shown in Figure 2.

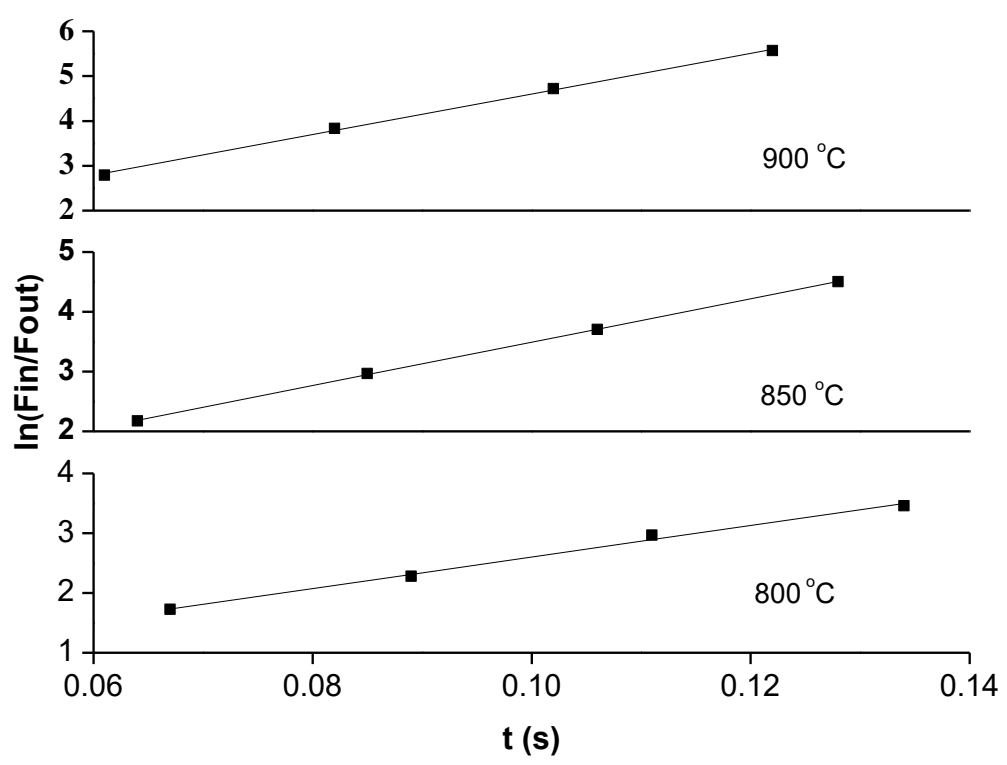

Figure 2. Effects of the residence time in the catalyst bed on $\ln (\mathrm{Fin} / \mathrm{Fout})$ under catalytic gasification temperature of $800^{\circ} \mathrm{C}, 850^{\circ} \mathrm{C}$, and $900^{\circ} \mathrm{C}$. (Dosage of char rose from 9 to $18 \mathrm{~g}$ at a rate of $3 \mathrm{~g}$, feeding rate of bio-oil was $47.02 \mathrm{~g} / \mathrm{h}$ and $\mathrm{S} / \mathrm{B}$ was 2$)$

The apparent rate constant of the bio-oil conversion over char was estimated according to the Arrhenius' law, seen in Equation 8. The estimated apparent activation energy of char was assumed to be constant in the studied temperature range (800 to $\left.900^{\circ} \mathrm{C}\right)$.

$$
k=k_{0} e^{\left(-E_{a} / R T\right)}
$$

where $k_{0}$ is the apparent frequency factor, $\mathrm{s}^{-1}$ and $E_{a}$ are the apparent activation energy $(\mathrm{J} / \mathrm{mol})$.

The Arrhenius plots and Cremer-Constable diagram of the catalytic gasification (800 to $900{ }^{\circ} \mathrm{C}$ ) are shown in Figure 3. The slopes and intercepts of the line were calculated by a linear regression to give the apparent activation energies $\left(E_{\mathrm{a}}\right)$ of $56.98 \mathrm{KJ} / \mathrm{mol}$ and the pre-exponential factors $\left(k_{0}\right)$ of $1.58 \times 10^{4} \mathrm{~s}^{-1}$ for a catalytic reforming with the char catalyst. It would be interesting to compare the results with the results of other researchers. However, research on the bio-oil conversion kinetic parameters for the biomass char could not be found. Only a comparison with tar reduction was made (Shan et al., 2018). The Charcoal in this work gave lower apparent activation energies $\left(E_{\mathrm{a}}\right)$ values in comparison to several different chars $(85.8 \mathrm{KJ} / \mathrm{mol}$ for sorbent-free coal char (Shamsi et al., 1996), $61 \mathrm{KJ} / \mathrm{mol}$ (El-Rub et al., 2008), $81.2 \mathrm{KJ} / \mathrm{mol}$ for foster wheeler 
char (Shamsi et al., 1996), BASF (58 KJ/mol) (Aznar, 1998), and G1-25 S (58 KJ/mol) (Aznar, 1998). And it gives pre-exponential factors $\left(k_{0}\right)$ higher than the commercial biomass char $\left(1.0 \times 10^{4} \mathrm{~s}^{-1}\right)$ (El-Rub et al., 2008), and foster wheeler char $\left(1.30 \times 10^{4} \mathrm{~s}^{-1}\right)$ (Shamsi et al., 1996). Therefore, bio-oil can be considered an easier removal than tar either from biomass gasification or coal gasification.

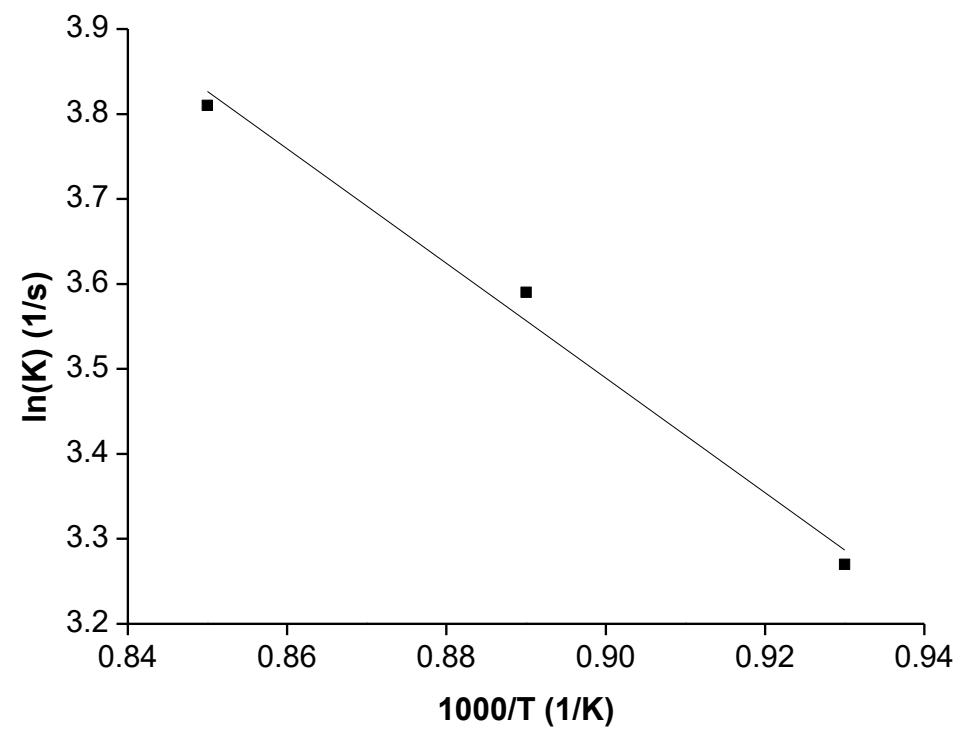

Figure 3. The relationship between apparent reaction rate constant and temperature according to Arrhenius' law

\section{Stability of the char catalyst on bio-oil catalytic reforming}

From the previous sections it was found that the bio-oil contents in the outlet dry gas was low under the catalytic reforming conditions, with a catalytic temperature of $900{ }^{\circ} \mathrm{C}, \mathrm{N}_{2}$ flow rate, $30 \mathrm{~mL} / \mathrm{min}$, WHSV, $2.6 \mathrm{~h}^{-1}$, a feeding rate of bio-oil, $47.02 \mathrm{~g} / \mathrm{h}$ and $\mathrm{S} / \mathrm{B}$ of 2. It was suitable for further catalytic steam reforming over the metal catalyst (Mengping et al., 2018). However, the stability of the char catalyst should be well understood (Chang et al., 2018). Thus, dry gas composition, bio-oil conversion, bio-oil contents in outlet dry gas, char waste, and the weight percentage of char consumed were studied as a function of time ( $\mathrm{Li}$ et al., 2019). The experimental results (Table 4) show that the increase in time resulted in the bio-oil contents of outlet dry gas to vary from decreasing to a slight increase, whereas the bio-oil conversion varied from increasing to a slight reduction (Zhang et al., 2018). These phenomena indicated that as time increased from $0.5 \mathrm{~h}$ to $1 \mathrm{~h}$, the char catalyst was consumed by steam and $\mathrm{CO}_{2}$, which produced new pores. In contrast, more alkali metals, such as $\mathrm{CaO}$ and $\mathrm{K}_{2} \mathrm{O}$ (Table 2), which have a better catalytic performance on the bio-oil gasification (Wang et al., 2018), were exposed on the char surface so that the catalytic performance of char increased. However, as the reaction time increased, more char catalysts are deactivation for sticking together. When the reaction time increased from 0.5 to $1 \mathrm{~h}$, the weight percentage of char catalyst consumption increased from 9.51 to $12.22 \%$, which confirmed that the char catalyst was consumed by steam and $\mathrm{CO}_{2}$ (Kang et al., 2017). As the reaction time increased from $1 \mathrm{~h}$ to $2 \mathrm{~h}$, the weight percentage of char consumed decreased to $4.02 \%$, which indicated that the coke deposition increased. All in all, the 
char catalyst exhibited an excellent bio-oil removal rate (bio-oil conversion $>99.6 \%$ ) in the first $2 \mathrm{~h}$. Aznar (1999) has confirmed in his work that in order to avoid deactivation of the catalyst by coke, the tar content in the gas product must be less than $2 \mathrm{~g} / \mathrm{Nm}^{3}$. In this work, the bio-oil contents of the outlet dry gas were lower than $1.89 \mathrm{~g} / \mathrm{Nm}^{3}$ in the first $2 \mathrm{~h}$, thus it is suitable for further catalytic steam reforming over a metal catalyst. The $\mathrm{CO}_{2}$ and $\mathrm{H}_{2}$ concentrations showed similar trends of a small increase, whereas both the $\mathrm{CO}$ and $\mathrm{CH}_{4}$ concentrations decreased as the reaction time rose. From the dry gas composition point of view, it is suitable for hydrogen production.

When the experiment was performed in nearly $3 \mathrm{~h}$, the water-metering pump could not feed water into the reactor because of the high pressure in the reactor. This was caused by char catalysts sticking together. A further study should include understanding on the reason for char sticking together and how to reduce such.

Table 4. Stability of char catalyst

\begin{tabular}{c|c|c|c|c|c|c|c|c}
\hline \multirow{2}{*}{ Time (h) } & \multicolumn{3}{|c|}{ Dry gas composition (vol.\%) } & \multicolumn{2}{c|}{ Bio-oil } & \multicolumn{2}{c}{ Char waste } \\
\cline { 2 - 9 } & $\mathbf{H}_{\mathbf{2}}$ & $\mathbf{C O}$ & $\mathbf{C H}_{\mathbf{4}}$ & $\mathbf{C O}_{\mathbf{2}}$ & $\begin{array}{c}\text { Conversion } \\
\text { (wt.\%) }\end{array}$ & $\begin{array}{c}\text { In the outlet dry } \\
\text { gas }\left(\mathbf{g} / \mathbf{N m}^{\mathbf{3}}\right)\end{array}$ & $\mathbf{g}$ & $\mathbf{w t . \%}$ \\
\hline 0.5 & 51.69 & 15.88 & 8.90 & 23.53 & 99.62 & 1.89 & 1.69 & 9.51 \\
1 & 52.74 & 14.25 & 8.80 & 24.20 & 99.91 & 0.38 & 2.31 & 12.22 \\
2 & 54.35 & 13.12 & 7.64 & 24.89 & 99.89 & 0.47 & 0.74 & 4.02 \\
\hline
\end{tabular}

\section{Reason for char sticking together and methods to overcome it}

There are three possible reasons for char sticking together, (1) the char catalysts tended to slag because of high alkali content and lower fusion temperatures, (2) as the char catalyst was consumed by steam and $\mathrm{CO}_{2}$, the framework of char collapsed, and (3) carbon deposition between the char catalysts. If char stickiness was mainly caused by slagging, the char catalyst would have a slower sticking rate under lower catalytic temperatures. To verify whether char sticking together was caused by slagging, a test was performed under the catalytic reforming conditions with a catalytic temperature of $800{ }^{\circ} \mathrm{C}, \mathrm{N}_{2}$ flow rate, $30 \mathrm{~mL} / \mathrm{min}$, WHSV, $1.9 \mathrm{~h}^{-1}$, feeding rate of bio-oil, $35 \mathrm{~g} / \mathrm{h}$ and a $\mathrm{S} / \mathrm{B}$ of 2 . The experimental results indicated that water also could not be fed into the reactor through the water-metering pump after $118 \mathrm{~min}$. Lower reaction temperatures caused char to stick faster, which indicated that slagging could not be the main factor causing the char to stick together. It is known that char catalysts always stick at the top of the char bed, which is near to the inlet of the reactor, and only a very small part of char stick together. Therefore, it is believed that the temperature at the top of the char bed is much lower than $900{ }^{\circ} \mathrm{C}$ for the continuously feeding thus carbon was formed. In other words, bio-oil and water need to be preheated. Prior to being fed into the catalytic reforming reactor, bio-oil, water, and $\mathrm{N}_{2}$ were preheated at $800{ }^{\circ} \mathrm{C}$. The catalytic reforming test was performed under conditions that were identical to the previous sections. The result shows that char sticking together and char collapsing were not found. This confirmed that char sticking together was caused only by carbon deposition between the char catalysts and preheating the bio-oil. It also confirmed that water was an effective method to overcome the char from sticking together. 


\section{Conclusions}

(1) When catalytic gasification temperatures were lower than $700{ }^{\circ} \mathrm{C}$, the bio-oil contents in the outlet dry gas were very high. Reforming product was not suitable for further catalytic steam reforming over a metal catalyst. The catalytic activity of char catalysts became very prominent at high temperatures $\left(\geq 800^{\circ} \mathrm{C}\right)$.

(2) The first order kinetic rate constant of char for bio-oil conversion, in the temperature range of 800 to $900{ }^{\circ} \mathrm{C}$, was found to have an apparent activation energy $\left(E_{\mathrm{a}}\right)$ of $56.98 \mathrm{KJ} / \mathrm{mol}$ and a pre-exponential factor $\left(k_{0}\right)$ of $1.58 \times 10^{4} \mathrm{~s}^{-1}$.

(3) Bio-oil contents in the outlet dry gas varied from decreasing to a slight increase in the first $2 \mathrm{~h}$ under the catalytic gasification conditions with a catalytic temperature of $900{ }^{\circ} \mathrm{C}$, WHSV , $2.6 \mathrm{~h}^{-1}$, feeding rate of bio-oil of $47.02 \mathrm{~g} / \mathrm{h}$ and S/B of 2. In comparison, bio-oil conversions vary from increasing to a slight reduction. All in all, the char catalyst exhibited an excellent bio-oil removal rate (bio-oil conversion $>99.6 \%$ ) and the bio-oil contents in the outlet dry gas were lower than $1.89 \mathrm{~g} / \mathrm{Nm}^{3}$, thus it was suitable for further catalytic steam reforming over a metal catalyst.

(4) The feeding materials temperature should be allowed to achieve the designed reaction temperature before reaching the char catalysts, to block the char catalysts from sticking together.

In the study of catalytic reforming of biomass pyrolysis oil for hydrogen production, only a small number of catalysts have been studied. It is necessary to study in depth the catalysts suitable for the reforming of biomass pyrolysis oil for hydrogen production with good selectivity, high activity and long life. In this way, the research on hydrogen production from Bio-oil reforming catalyzed by activated carbon will make progress in the future.

Acknowledgements. This work is supported by the Natural Science Foundation of China No. 21506087.

\section{REFERENCES}

[1] Arandia, A., Remiro, A., García, V. et al. (2018): Oxidative steam reforming of raw biooil over supported and bulk Ni catalysts for hydrogen production. - Catalysts 8(8): 322.

[2] Asghar, Z., Ali, W., Nasir, A., Arshad, A. (2018): Atmospheric monitoring for ambient air quality parameters and source apportionment of city Faisalabad, Pakistan. - Earth Sciences Pakistan 2(1): 01-04.

[3] Aznar, M. P. (1998): Commercial steam reforming catalysts to improve biomass gasification with steam-oxygen mixtures. Catalytic tar removal. - Industrial \& Engineering Chemistry Research 37(7): 2668-2680.

[4] Bizkarra, K., Barrio, V. L., Gartzia-Rivero, L. et al. (2018): Hydrogen production from a model bio-oil/bio-glycerol mixture through steam reforming using Zeolite L supported catalysts. - International Journal of Hydrogen Energy. https://doi.org/10.1016/j.ijhydene.2018.11.079.

[5] Chang, H., Wang, Z., Li, Y. X., Chen, G. R. (2018): Dynamics analysis of a bistable bilocal active memristor and its associated oscillator system. - International Journal of Bifurcation and Chaos 28(08).

[6] Cho, M. H., Mun, T. Y., Choi, Y. K. et al. (2014): Two-stage air gasification of mixed plastic waste: olivine as the bed material and effects of various additives and a nickelplated distributor on the tar removal. - Energy 70(3): 128-134. 
[7] Corella, J., Aznar, M. P., Delgado, J. et al. (1991): Steam gasification of cellulosic wastes in a fluidized bed with downstream vessels. - Industrial \& Engineering Chemistry Research 30(10): 2252-2262.

[8] Czernik, S., French, R. (2014): Distributed production of hydrogen by auto-thermal reforming of fast pyrolysis bio-oil. - International Journal of Hydrogen Energy 39(2): 744-750.

[9] Daniel, G. I., Henry, O. U., Ayodeji, B. B., Silas, M. Y. (2018): Land suitability analysis for the production of Cocoyam Inbenue State, Nigeria. - Earth Sciences Malaysia 2(2): 25-30.

[10] El-Rub, Z. A., Bramer, E. A., Brem, G. (2008): Experimental comparison of biomass chars with other catalysts for tar reduction. - Fuel 87(10-11): 2243-2252.

[11] Hayashi, J. I., Iwatsuki, M., Morishita, K. et al. (2002): Roles of inherent metallic species in secondary reactions of tar and char during rapid pyrolysis of brown coals in a droptube reactor. - Fuel 81(15): 1977-1987.

[12] Hosokai, S., Hayashi, J. I., Shimada, T. et al. (2005): Spontaneous generation of tar decomposition promoter in a biomass steam reformer. - Chemical Engineering Research \& Design 83(9): 1093-1102.

[13] Hossain, M. S., Karlson, M., Neset, T. S. (2019): Application of GIS for cyclone vulnerability analysis of Bangladesh. - Earth Sciences Malaysia 3(1): 25-34.

[14] Ilyas, M., Ali, M. A., Awan, A. N., Haider, S., Shahid, A. (2019): Estimation of noise levels in the road side parks and study of its impacts on health of visitors in Faisalabad. Earth Sciences Pakistan 3(1): 14-22.

[15] Kai, W., Shengzhe, Z., Yanting, Z., Jun, R., Liwei, L., Yong, L. (2018): Synthesis of porous carbon by activation method and its electrochemical performance. - Int. J. Electrochem. Sci 13(11): 10766-10773.

[16] Kang, L., Zhang, Y. J., Zhang, L., Zhang, K. (2017): Preparation, characterization and photocatalytic activity of novel $\mathrm{CeO}_{2}$ loaded porous alkali-activated steel slag-based binding material. - International Journal of Hydrogen Energy 42(27): 17341-17349.

[17] Li, C. Z. (2007): Some recent advances in the understanding of the pyrolysis and gasification behaviour of Victorian brown coal. - Fuel 86(12): 1664-1683.

[18] Li, C., Li, S., Tian, Q. (2019): Microbial attachment behavior and pollutant removal performance of modified quartz sand. - Acta Microscopica 28(2).

[19] Li, W. Z., Yan, Y. J., Li, T. C. et al. (2008): Preparation of hydrogen via catalytic gasification of residues from biomass hydrolysis with a novel high strength catalyst. Energy \& Fuels 22(2): 1233-1238.

[20] Li, Y., Zhang, C. S., Liu, Y. G. et al. (2017): Coke formation on the surface of Ni/HZSM5 and Ni-Cu/HZSM-5 catalysts during bio-oil hydrodeoxygenation. - Fuel 189: 23-31.

[21] Li, Y., Cheng, H., Wang, J., Wang, Y. (2018): Dynamic analysis of unilateral diffusion Gompertz model with impulsive control strategy. - Advances in Difference Equations 2018(1): 32 .

[22] Masri, E., Samsudin, M. D. M. (2018): Optimization performance of biological cathodic protection system using organic waste. - Environment \& Ecosystem Science 2(2): 25-29.

[23] Min, Z. H., Yimsiri, P., Asadullah, M. et al. (2011): Catalytic reforming of tar during gasification. Part II. Char as a catalyst or as a catalyst support for tar reforming. - Fuel 90(7): 2545-2552.

[24] Mun, T. Y., Seon, P. G., Kim, J. S. (2010): Production of a producer gas from woody waste via air gasification using activated carbon and a two-stage gasifier and characterization of tar. - Fuel 89(11): 3226-3234.

[25] Naidu, M. T., Premavani, D., Suthari, S., Venkaiah, M. (2018): Assessment of tree diversity in tropical deciduous forests of Northcentral Eastern Ghats, India. - Geology, Ecology, and Landscapes 2(3): 216-227. 
[26] Nestler, F., Burhenne, L., Amtenbrink, M. J. et al. (2016): Catalytic decomposition of biomass tars: the impact of wood char surface characteristics on the catalytic performance for naphthalene removal. - Fuel Processing Technology 145: 31-41.

[27] Omini, E. O., Akpang, O. M. (2018): Cavity detection under re-enforced concrete floor using ground penetration radar. - Engineering Heritage Journal 2(2): 11-18.

[28] Shan, P. F., Lai, X. P. (2018): Numerical simulation of the fluid-solid coupling process during the failure of a fractured coal-rock mass based on the regional geostress characteristics. - Transport in Porous Media 124(3): 1061-1079.

[29] Park, J., Lee, Y., Ryu, C. (2016): Reduction of primary tar vapor from biomass by hot char particles in fixed bed gasification. - Biomass and Bioenergy 90: 114-121.

[30] Qian, K. Z., Kumar, A. (2015): Reforming of lignin-derived tars over char-based catalyst using Py-GC/MS. - Fuel 162: 47-54.

[31] Rajput, K., Gupta, A., Arushi (2019): Re-cycle of e-waste in concrete by partial replacement of coarse aggregate. - Engineering Heritage Journal 1(1): 05-08.

[32] Shamsi, A. (1996): Catalytic and thermal cracking of coal-derived liquid in a fixed-bed reactor. - Industrial \& Engineering Chemistry Research 35(4): 1251-1256.

[33] Sharma, D., Yadav, K. D. (2018): Application of rotary in-vessel composting and analytical hierarchy process for the selection of a suitable combination of flower waste. Geology, Ecology, and Landscapes 2(2): 137-147.

[34] Thakkar, M., Makwana, J. P., Mohaty, P. et al. (2016): In bed catalytic tar reduction in the autothermal fluidized bed gasification of rice husk: extraction of silica, energy and cost analysis. - Industrial Crops and Products 87: 324-332.

[35] Valle, B., Aramburu, B., Benito, P. L. et al. (2018): Biomass to hydrogen-rich gas via steam reforming of raw bio-oil over $\mathrm{Ni} / \mathrm{La}_{2} \mathrm{O}_{3}-\mathrm{\alpha Al}_{2} \mathrm{O}_{3}$ catalyst: effect of space-time and steam-to-carbon ratio. - Fuel 216: 445-455.

[36] Wang, D., Czernik, S., Chornet, E. (1998): Production of hydrogen from biomass by catalytic steam reforming of fast pyrolysis oils. - Energy \& Fuels 12: 19-24.

[37] Wang, K., Zhou, S. Z., Zhou, Y. T., Ren, J. et al. (2018): Synthesis of porous carbon by activation method and its electrochemical performance. - International Journal of Electrochemical Science 13(11): 10766-10773.

[38] Wang, Z. X., Pan, Y., Dong, T. et al. (2007): Production of hydrogen from catalytic steam reforming of bio-oil using C12A7-O-based catalysts. - Applied Catalysis A: General 320(3): 24-34.

[39] Wu, C., Huang, Q., Sui, M. et al. (2008): Hydrogen production via catalytic steam reforming of fast pyrolysis bio-oil in a two-stage fixed bed reactor system. - Fuel Processing Technology 89(12): 1306-1316.

[40] Xing, M. P., Shen, H., Wang, Z. (2018): Hळ synchronization of semi-Markovian jump neural networks with randomly occurring time-varying delays. - Complexity 2018: 16. DOI: $10.1155 / 2018 / 8094292$.

[41] Yahya, N., Aziz, F., Enriquez, M. A. O., Aizat, A., Jaafar, J., Lau, W. J., Yusof, N., Salleh, W. N. W., Ismail, A. F. (2018): Preparation and characterization of Lafeo3 using dual-complexing agents for photodegradation of humic acid. - Environment \& Ecosystem Science 2(2): 30-34.

[42] Yang, Y. X., Li, H., Zheng, W. K., Bai, Y., Liu, Z. M., Zhang, J. J. (2019): Experimental study on calcining process of secondary coated ceramsite solidified chromium contaminated soil. - Science of Advanced Materials 11(2): 208-214.

[43] Zanzi, R., Sjostrom, K., Bjornbom, E. (1996): Rapid high-temperature pyrolysis of biomass in a free-fall reactor. - Fuel 75(5): 545-550.

[44] Zeng, D. W., Xiao, R., Zhang, S. et al. (2015): Bio-oil heavy fraction for hydrogen production by iron-based oxygen carrier redox cycle. - Fuel Processing Technology 139: $1-7$. 
[45] Zhang, J., Xia, J. W., Sun, W., Zhuang, G. G., Wang, Z. (2018): Finite-time tracking control for stochastic nonlinear systems with full state constraints. - Applied Mathematics and Computation 338: 207-220.

[46] Zhang, S., Song, Y., Song, Y. C. et al. (2016): An advanced biomass gasification technology with integrated catalytic hot gas cleaning. Part III: Effects of inorganic species in char on the reforming of tars from wood and agricultural wastes. - Fuel 183: 177-184.

[47] Zhang, W. P., Yang, J. Z., Fang, Y. L., Chen, H. Y., Mao, Y. H., Kumar, M. (2017): Analytical fuzzy approach to biological data analysis. - Saudi Journal of Biological Sciences 24(3): 563-573.

[48] Zhang, Y. H. (2018): In-situ IR study for elucidating the adsorption cracking mechanism of toluene over calcined olivine catalyst. - International Journal of Hydrogen Energy 43: 15835-15842.

[49] Zhou, D., Gao, F., Breaz, E., Ravey, A., Miraoui, A. (2017a): Degradation prediction of PEM fuel cell using a moving window based hybrid prognostic approach. - Energy 138: 1175-1186.

[50] Zhou, D., Al-Durra, A., Gao, F., Ravey, A., Matraji, I., Godoy Simões, M. (2017b): Online energy management strategy of fuel cell hybrid electric vehicles based on data fusion approach. - Journal of Power Sources 366(31): 278-291. 